\title{
Blackfly Larvae (Simulium spp.) Can Intensify Methylmercury Biomagnification in Boreal Food Webs
}

\author{
Anna K. Karjalainen $(\mathbb{D}) \cdot$ Johanna Salmelin • Brian \\ Dimock • Holger Hintelmann
}

Received: 10 January 2020 / Accepted: 23 June 2020 /Published online: 16 July 2020

(C) The Author(s) 2020

\begin{abstract}
Global pollution of mercury $(\mathrm{Hg})$ threatens ecosystem and human health. We measured total $\mathrm{Hg}$ $(\mathrm{THg})$ and monomethylmercury $(\mathrm{MMHg})$ concentrations in filter-feeding blackfly (Simulium spp.) larvae in the inflows and the outflows of six boreal lakes with no $\mathrm{Hg}$ point source pollution. $\mathrm{THg}$ in the larvae ranged from 0.03 to $0.31 \mathrm{mg} \mathrm{kg}^{-1} \mathrm{dw}$ and MMHg between 0.02 and $0.25 \mathrm{mg} \mathrm{kg}^{-1} \mathrm{dw}$. The proportion of MMHg in the larvae was $74 \pm 0.16 \%$ and ranged from 43 to $98 \%$ of $\mathrm{THg}$, the highest proportions being comparable to those typically found in aquatic predatory insects and fish. We compared the larvae MMHg concentrations to river water quality, catchment land-use, and to size-adjusted lake pike THg data. Two of the investigated catchments have been affected by a multimetal biomine since 2008 and were characterized by higher conductivity and higher urban land-use activity. Larvae $\mathrm{THg}$ and $\mathrm{MMHg}$ concentrations were higher in the lake inflows than in outflows and associated with water conductivity and catchment land-use activity. Lake pike THg concentrations were highly correlated to lake outflow blackfly larvae MMHg concentrations. Our data illustrate that blackfly larvae take up high percentage of $\mathrm{THg}$ that is
\end{abstract}

\footnotetext{
A. K. Karjalainen $(\bowtie) \cdot$ J. Salmelin

Department of Biological and Environmental Science, University of Jyväskylä, PO Box 35, FI-40014 University of Jyväskylä, Finland

e-mail: anna.k.karjalainen@jyu.fi

B. Dimock $\cdot$ H. Hintelmann

School of the Environment, Trent University, Peterborough, Ontario, Canada
}

MMHg, which in turn is available for higher consumers in aquatic and terrestrial food webs.

Keywords Total mercury · Methylmercury $\cdot$ Simuliidae larvae $\cdot$ Bioaccumulation $\cdot$ Freshwater

\section{Introduction}

Mercury ( $\mathrm{Hg}$ ) contamination is a global threat to ecosystems and human health. Mercury is emitted to air by anthropogenic activities, most importantly coal burning, mining, industrial activities that process ores to produce various metals or process other raw materials to produce cement (UNEP 2013). The emitted Hg is transported over long distances throughout the world, and Nordic ecosystems are affected by the ensuing $\mathrm{Hg}$ deposition (Munthe et al. 2007; Braaten et al. 2017).

Atmospheric depositing $\mathrm{Hg}$ is captured effectively by forests, and $\mathrm{Hg}$ predominantly enters the soils with leaf litter (Ward et al. 2010). Land-use activities such as forest clear cutting, forest and wetland ditching, peat production, and mining are known to increase $\mathrm{Hg}$ loading to aquatic ecosystems in boreal catchments by releasing the deposited $\mathrm{Hg}$ when the ground and its microbial activity is disrupted (Porvari et al. 2003; UNEP 2013; Wu et al. 2018). Once having entered aquatic ecosystems, Hg becomes subject of natural biomethylation reactions by anaerobic bacteria, which are capable of transforming inorganic mercury into organic and the most toxic form, methylmercury (monomethylmercury, $\mathrm{MMHg}$ ). Bacterial methylation of $\mathrm{Hg}$ and counteracting 
demethylation are not restricted to wetlands and other aquatic systems, but can occur already in suitable conditions in disturbed and wetted soils (Bishop et al. 2020; Eklöf et al. 2018). Anthropogenic land-use activities are often manifested in the corresponding river water quality as increased loading of dissolved organic material (DOM), increased conductivity, and increased acidity (observed as decreased $\mathrm{pH}$ ). MMHg in turn can accumulate in high concentrations in food chains up to predatory fish and humans consuming fish (e.g. Watras et al. 1998), and this Hg biomagnification can be enhanced after forest harvesting (Wu et al. 2018).

Metal mining is one of the anthropogenic activities, which can cause sulfate $\left(\mathrm{SO}_{4}\right)$ loading into aquatic systems. Excess $\mathrm{SO}_{4}$ is likely to produce favorable conditions for the sulfate-reducing bacteria (SRB), known to be the main $\mathrm{Hg}$ methylators (Compeau and Bartha 1985; Gilmour et al. 1992; King et al. 1999), and known to interact synergistically with $\mathrm{Hg}$ input to yield larger amounts of $\mathrm{MeHg}$ than would be expected otherwise (Watras 2009). This raises an additional cause for concern in regards of $\mathrm{Hg}$ risks in mining-affected aquatic systems, because it may lead to increased uptake of MMHg by organisms and finally, increased biomagnification of $\mathrm{MMHg}$. The risk is further pronounced if $\mathrm{SO}_{4}$ loading leads to permanent stratification of the water system (meromixis and anoxia in hypolimnion) such as in two of the lakes affected by biomining in Finland, and one of the lakes included in the current study, L. Kivijärvi (Karjalainen et al. 2020; Leppänen et al. 2017).

In fish, MMHg accumulates to their edible parts (muscle). High MMHg levels in edible parts of predatory fish species are a serious health concern because the safety margin for consumption of fish fillet is small in many places of the world (e.g. Driscoll et al. 2013; Karjalainen et al. 2013; Leino et al. 2013; Munthe et al. 2007; UNEP 2013). The European Union mandates its member states to monitor $\mathrm{Hg}$ concentrations in fish (EU 2013). Monitoring is implemented in boreal regions by catching wild perch (Perca fluviatilis), because they are a common species, easy to catch yearround, show predatory status in the food web, and so accumulate MMHg (Verta et al. 2010). Alternative species commonly used for $\mathrm{Hg}$ monitoring in fish fillet is the predatory pike (Esox lucius). Monitoring is often implemented by measuring $\mathrm{THg}$ concentrations in fish fillet, because analysis of total $\mathrm{Hg}(\mathrm{THg})$ is substantially more straight forwarded, cheaper, and the proportion of $\mathrm{MMHg}$ to $\mathrm{THg}$ in the muscle of the predatory fish is well known. Typically, in predatory fish, the percentage of MMHg is 95\% of THg (Bloom 1992; Lasorsa and Allen-Gil 1995; Westöö 1973).

Blackfly larvae (Diptera, Simuliidae) living in lotic aquatic environments feed mostly on fine particulate organic material containing DOM and bacteria, and to a lesser extent, algae (Ciborowski et al. 1997; Hershey et al. 1996). In aquatic environments, DOM is known to effectively bind inorganic $\mathrm{Hg}$ and $\mathrm{MMHg}$, which can facilitate bioaccumulation of $\mathrm{MMHg}$ in aquatic food webs (Driscoll et al. 2013; Haitzer et al. 2003; Ravichandran 2004). Blackfly larvae can thus directly take up DOM-bound MMHg from the water column. Harding et al. (2006) have found that blackfly larvae from soft-water streams in Ontario, Canada, contain high concentrations of THg. They have concluded that the larvae can be a significant entry point for $\mathrm{Hg}$ ( $\mathrm{THg}$ and $\mathrm{MMHg}$ ) into the food web and that accumulation of $\mathrm{Hg}$ by blackfly larvae was affected by stream $\mathrm{pH}, \mathrm{DOM}$, and wetland area in the stream catchment. Because catchment abiotic and biotic processes are complex and area specific, it is unclear, however, how various of human activities in different catchments can affect $\mathrm{Hg}$ uptake in blackfly larvae directly or indirectly. Larvae themselves are an important part of the ecosystems of most lotic waters and a prey for various insects and fish (Jensen 1997; Malmqvist and Sackmann 1996), which can accumulate high concentrations of MMHg through their diet, and are in turn available for higher consumers in aquatic and terrestrial food webs. Furthermore, blackfly larvae are easy to gather, can occur in enormous quantities in one habitat, and have a worldwide distribution in lotic waters (Adler and Crosskey 2016; Jensen 1997).

The current objective was to determine total and monomethylmercury concentrations and $\mathrm{MMHg}$ to THg proportions in North European blackfly larvae, in inflows and outflows of northern European lakes with various land-use activities in their catchments. Two of the study lakes have received metal biomining effluents since 2008, which is indicated by higher water conductivity. One major interest was to assess if biomining and other land-use activities and related water quality influences larvae $\mathrm{Hg}$ concentrations. In addition, larvae mercury concentrations in lake inflows and outflows as well as with the lake pike THg concentrations are compared. Lake inflows are affected by smaller subcatchment than outflows, which is affected by the whole lake catchment upstream. Lake predatory fish $\mathrm{THg}$ concentrations 
could be correlated to lake outflow blackfly larvae MMHg concentrations but not to inflow, because outflows are more representative of lake physicochemical characteristics and processes. Therefore, water quality in the larvae habitats was measured on site, and the available lake inflow and outflow catchment land-use activity data and pike $\mathrm{THg}$ concentrations data were retrieved from the available databases and literature and used as independent variables in the analyses. Examining $\mathrm{THg}$ and $\mathrm{MMHg}$ concentrations in blackfly larvae and their associations with river water quality, catchment landuse and $\mathrm{THg}$ in predatory fish enables us to understand the larvae role in $\mathrm{Hg}$ biomagnification, and whether they are useful indicators in assessing the biomagnification potential of Hg. To the best of our knowledge, this is the first time total and monomethylmercury concentrations have been measured in blackfly larvae in Finland and have been compared to the factors described above.

\section{Material and Methods}

\subsection{Study Sites}

Six lakes with their inflows and outflows were chosen for the study based on known $\mathrm{Hg}$ concentrations in lake sediments and/or fish and assumed blackfly larvae habitats. The $\mathrm{Hg}$ levels of the study lakes were known to be higher than in the other lakes nearby. The lake inflows (IF) and outflows (OF) for the six study sites were rivers Myllyjoki $\left(62^{\circ} 11^{\prime} 47.3^{\prime \prime} \mathrm{N}, 25^{\circ} 28^{\prime} 32.8^{\prime \prime} \mathrm{E}\right)$ and Muuratjoki $\left(62^{\circ} 07^{\prime} 40.5^{\prime \prime} \mathrm{N}, 25^{\circ} 40^{\prime} 16.8^{\prime \prime} \mathrm{E}\right)$ for L. Muuratjärvi; rivers Pengerkoski (62 $62^{\circ} 17^{\prime} 04.3^{\prime \prime} \mathrm{N}, 25^{\circ}$ $\left.07^{\prime} 15.1^{\prime \prime} \mathrm{E}\right)$ and Piesalanjoki $\left(62^{\circ} 12^{\prime} 21.9^{\prime \prime} \mathrm{N}, 25^{\circ} 11^{\prime}\right.$ $10.7^{\prime \prime}$ E) for L. Petäjävesi; rivers Hohonjoki $\left(62^{\circ} 15^{\prime}\right.$ $\left.32.3^{\prime \prime} \mathrm{N}, 26^{\circ} 15^{\prime} 50.8^{\prime \prime} \mathrm{E}\right)$ and Tarvaalankoski $\left(62^{\circ} 23^{\prime}\right.$ $\left.12.4^{\prime \prime} \mathrm{N}, 26^{\circ} 03^{\prime} 12.2^{\prime \prime} \mathrm{E}\right)$ for L. Lievestuoreenjärvi; rivers Tuohenjoki $63^{\circ} 45^{\prime} 05.3^{\prime \prime} \mathrm{N}, 28^{\circ} 16^{\prime} 31.5^{\prime \prime} \mathrm{E}$ ) and Ukonjoki ( $\left.63^{\circ} 47^{\prime} 38.6^{\prime \prime} \mathrm{N}, 28^{\circ} 10^{\prime} 47.1^{\prime \prime} \mathrm{E}\right)$ for L. Ukonjärvi, rivers Lumijoki ( $63^{\circ} 56^{\prime} 06.1^{\prime \prime} \mathrm{N}, 27^{\circ} 55^{\prime}$ 28.1" E) and Kivijoki (63 54' 55.3" N, $27^{\circ} 54^{\prime}$ 51.6" E) for L. Kivijärvi; and rivers Tuhkajoki $\left(64^{\circ} 02^{\prime} 34.0^{\prime \prime} \mathrm{N}\right.$, $\left.28^{\circ} 06^{\prime} 38.2^{\prime \prime} \mathrm{E}\right)$ and Jormasjoki (64 $07^{\prime} 39.8^{\prime \prime} \mathrm{N}, 28^{\circ}$ $05^{\prime} 28.4^{\prime \prime}$ E) for L. Jormasjärvi (Fig. 1, Table 1). Three of the study sites were located in Central Finland with catchments of small cities on the lakeshores and some agricultural and forestry activities. They were rivers Myllykoski and Muuratjoki in L. Muuratjärvi catchment, Pengerkoski and Piesalanjoki in L. Petäjävesi catchment and rivers Hohonjoki and Tarvaalankoski in L. Lievestuoreenjärvi catchment. Tarvaalankoski outflow is a rapid located further from L. Lievestuoreenjärvi and as such, represents a larger waterway. All other investigated inflows and outflows were directly connected to the lakes. Two of the study sites were situated near an open-bit multimetal mine and have received biomining effluents since 2008. They were rivers Tuhkajoki and Jormasjoki in L. Jormasjärvi catchment and rivers Lumijoki and Kivijoki in L. Kivijärvi catchment. The Terrafame mining company (formerly Talvivaara Mining Company) started biomining activities in the area in 2008. This mine uses bacterial bioheap leaching to recover metals $(\mathrm{Ni}, \mathrm{Zn}, \mathrm{Co}$, $\mathrm{Cu}$ ) from ores and has caused adverse effects to the waterways receiving the effluents (Karjalainen et al. 2020; Leppänen et al. 2017; Salmelin et al. 2017; Wallin et al. 2018). However, on some occasions, adverse effects towards biota were not observed, e.g., whitefish and trout eggs survival incubated in river bottoms was comparable with that in reference rivers (Arola et al. 2019). Detailed water chemistry in the two catchments, River Oulujoki and Vuoksi, rivers in the area affected by the mine during 2012-2015 can be seen in Arola et al. (2019), Karjalainen et al. (2020), Salmelin et al. (2017), and Sivula et al. (2018). Pristine dystrophic L. Ukonjärvi catchment (IF: Tuohenjoki, OF: Ukonjoki), situated near the mining-affected lakes, has not received the mining effluents, but was subject to forestry and peat mining activities in its catchment.

\subsection{Blackfly Larvae Collection and Handling}

Blackfly larvae were sampled from their typical habitats in river riffles where they attach themselves on solid substrates such as rocks and riparian vegetation. North European blackflies typically pass through four to eight developmental stages, called instars, and the early instar stages last shorter than the later (Jensen 1997). The whole larval stage of the life cycle can greatly vary in length depending on the time of the year and the temperature. After the final instar stage, the larva forms a pupa prior its emergence of adult blackfly. The larvae and pupa are only found in running waters.

River sites were inspected for suitable riffles with larvae presence, and blackflies were sampled in both lake inflows and outflows at water depths of $8( \pm 8) \mathrm{cm}$. The aim was to sample as similar sized as well as older developmental stages as possible. Water velocity (Höntzsch Instruments, 
Fig. 1 Map of the study rivers in Finland, located in three watersheds indicated by red lines, from north to south: Oulujoki, Vuoksi, and Kymijoki watersheds. The mining district of Terrafame mine is shown in hatched pattern, and four nearby rivers affected by mine effluents are depicted with black squares: Tuhkajoki, Jormasjoki, Lumijoki, and Kivijoki. Rivers that are not affected by mining are depicted by red circles. Maps were constructed by ArcGIS®10.5.1 (ESRI Inc., Redlands, CA). Map of Europe @ESRI Data \& Maps 9.3.1, 2009; general and topographic maps of Finland, (C) National Land Survey of Finland, 07/2018; catchment areas, National Database of Regional Land Use Plans, (C)Finnish Environment Institute 2018

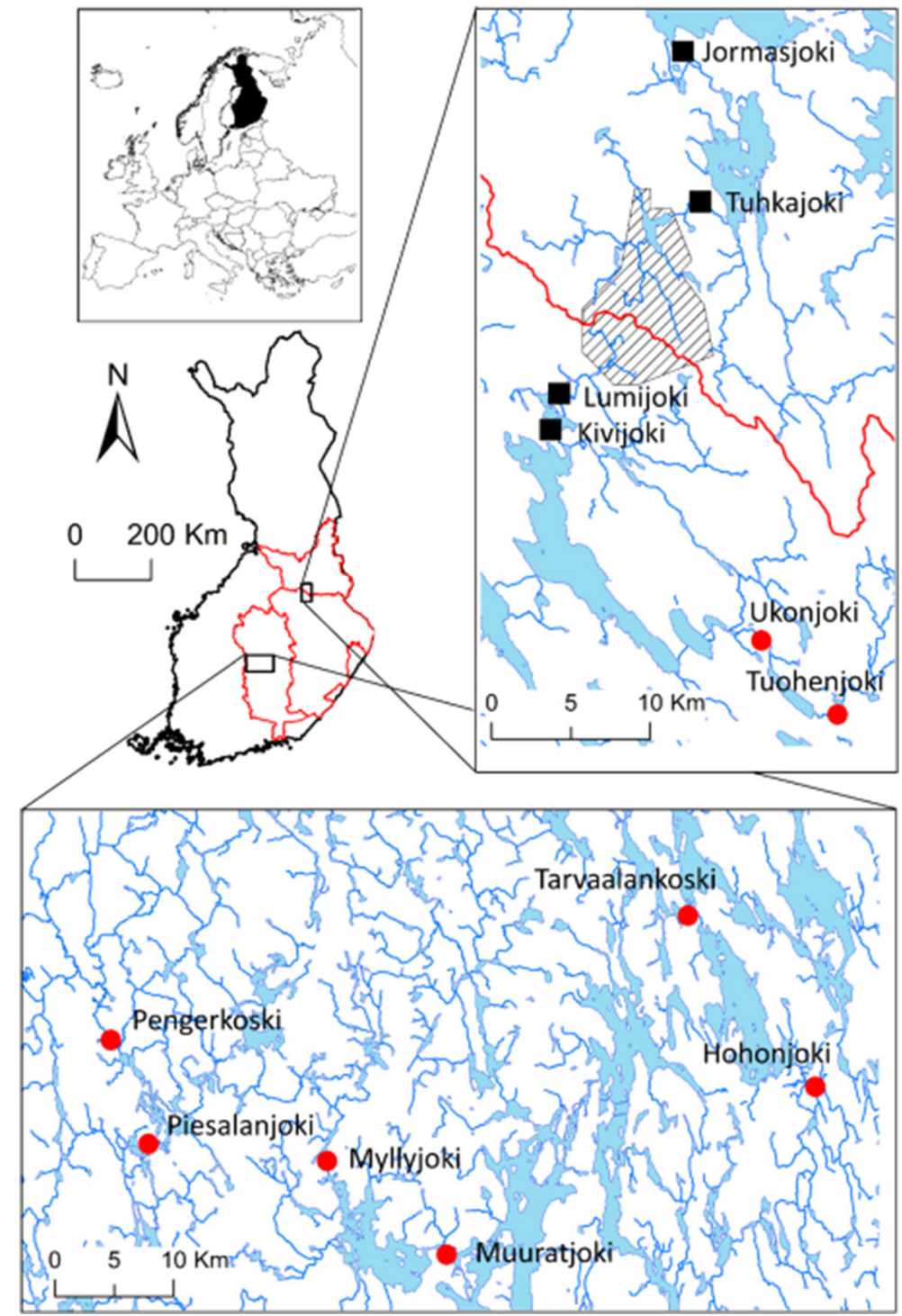

Germany) of the chosen river riffle(s) was measured at the depth where the larvae were found and ranged from 0.4 to $1.0 \mathrm{~m} \mathrm{~s}^{-1}$. If enough individuals were found, the larvae were sampled from a single riffle (rivers Myllyjoki, Hohonjoki, Tarvaalankoski, Tuohenjoki, Ukonjoki, Jormasjoki, and Kivijoki). In other cases, the larvae were gathered from sequential river riffles (rivers Muuratjoki, Pengerkoski, Piesalanjoki, Tuhkajoki, and Lumijoki). Blackfly larvae were sampled within 2 weeks from late May to early June 2016 (between May 24th and June 8th), proceeding from south to north. Larvae weighing $2.63 \pm$ $0.86 \mathrm{mg} \mathrm{ww}$ and representing several larval stages up to the 8th stage were gathered into $10 \mathrm{~L}$ acid washed (1 M sp. $\mathrm{HNO}_{3}$ and triplicate rinse with ultrapure deionized water,
Ultra Clear UV plus TM, Siemens Water Technologies) polypropylene containers. Pupal stages were gathered in rivers Myllykoski, Muuratjoki, and Piesalanjoki, and their weights are reported as additional information.

Larvae were transported to the laboratory in their well-aerated river waters in temperature-controlled coolers. A few larvae from each river were preserved in $75 \%$ ethanol in $20-\mathrm{mL}$ class scintillation vials for genus and larval stage identification. Larvae were then transferred into pre-aerated soft organic-free artificial freshwater (ISO 6341 1996, Ca-Mg hardness $1 \mathrm{mM}$ ) made from ultrapure deionized water and the gut contents were purged for 12-16 h after sampling. Each river-specific sample consisted of dozens to hundreds 
Table 1 Lake surface area and mean depths, and lake inflow (IF) and outflow (OF) river catchment land-use activities (\%). Lakes Kivijärvi and Jormasjärvi have received mining effluents through their inflow rivers Lumijoki and Tuhkajoki since 2008

\begin{tabular}{|c|c|c|c|c|c|c|c|c|c|c|}
\hline \multirow[t]{2}{*}{ Lake } & \multirow{2}{*}{$\begin{array}{l}\text { Lake } \\
\text { surface } \\
\text { area, } \\
\mathrm{km}^{2}\end{array}$} & \multirow{2}{*}{$\begin{array}{l}\text { Lake } \\
\text { mean } \\
\text { depth, } \\
\text { m }\end{array}$} & \multirow[t]{2}{*}{ Study rivers } & \multirow{2}{*}{$\begin{array}{l}\text { Catchment } \\
\text { size, } \mathrm{km}^{2}\end{array}$} & \multicolumn{6}{|c|}{ Catchment land-use, $\%$} \\
\hline & & & & & Urban $^{\mathrm{a}}$ & Mining $^{\mathrm{b}}$ & Agriculture $^{\mathrm{c}}$ & Forested $^{\mathrm{d}}$ & Wetlands & $\begin{array}{l}\text { Open } \\
\text { water }\end{array}$ \\
\hline \multirow[t]{2}{*}{ Muuratjärvi } & \multirow[t]{2}{*}{31.0} & \multirow[t]{2}{*}{13.5} & IF: Myllyjoki & 133 & 5.3 & 0.6 & 4.5 & 82.6 & 1.2 & 6.9 \\
\hline & & & OF: Muuratjoki & 385 & 4.4 & 0.3 & 5.1 & 77.9 & 0.8 & 12.1 \\
\hline \multirow[t]{2}{*}{ Petäjävesi } & \multirow[t]{2}{*}{8.8} & \multirow[t]{2}{*}{4.2} & IF: Pengerkoski & 408 & 1.4 & 0.1 & 4.5 & 89.2 & 2.5 & 2.4 \\
\hline & & & OF: Piesalanjoki & 664 & 2.3 & 0.1 & 4.7 & 85.4 & 1.8 & 5.8 \\
\hline \multirow[t]{2}{*}{ Lievestuoreenjärvi } & \multirow[t]{2}{*}{40.2} & \multirow[t]{2}{*}{9.9} & IF: Hohonjoki & 124 & 3.5 & 0.1 & 11.3 & 81.7 & 1.1 & 2.8 \\
\hline & & & OF: Tarvaalankoski & 7305 & 2.5 & 0.1 & 5.9 & 70.3 & 1.4 & 19.9 \\
\hline \multirow[t]{2}{*}{ Ukonjärvi } & \multirow[t]{2}{*}{2.4} & \multirow[t]{2}{*}{4.4} & IF: Tuohenjoki & 65 & 0.1 & 0.1 & 0 & 92.1 & 6.6 & 1.6 \\
\hline & & & OF: Ukonjoki & 84 & 0.1 & 0.1 & 0 & 90.5 & 5.7 & 4.1 \\
\hline \multirow[t]{2}{*}{ Kivijärvi } & \multirow[t]{2}{*}{1.9} & \multirow[t]{2}{*}{3.2} & IF: Lumijoki & 33 & 17.9 & 17.2 & 0 & 79.2 & 2.8 & 0.7 \\
\hline & & & OF: Kivijoki & 53 & 11.2 & 10.7 & 0 & 82.1 & 2.7 & 4.5 \\
\hline \multirow[t]{2}{*}{ Jormasjärvi } & \multirow[t]{2}{*}{20.5} & \multirow[t]{2}{*}{5.8} & IF: Tuhkajoki & 125 & 5.2 & 4.3 & 0.9 & 89.6 & 1.6 & 3.3 \\
\hline & & & OF: Jormasjoki & 299 & 3.2 & 2.1 & 1.5 & 85.5 & 1.5 & 8.6 \\
\hline
\end{tabular}

${ }^{\mathrm{a}}$ All anthropogenic land-use activities related to residential, recreational, industrial, services, traffic and transport, landfill, construction sites, and soil excavation

${ }^{\mathrm{b}}$ Mining-related urban land-use activities such as landfill, construction sites, and soil excavation separately

${ }^{\mathrm{c}}$ Farmlands, pasturelands, and other heterogenic agricultural areas

${ }^{\mathrm{d}}$ Young and old forests, brushes, and moors

of larvae, and the sample was further subdivided after gut purging with plastic Pasteur pipettes for $\mathrm{THg}$ and $\mathrm{MMHg}$ analyses and for average wet and dry weight determinations into $20-\mathrm{mL}$ glass scintillation vials (Fisher Scientific). Larvae for the $\mathrm{THg}$ and $\mathrm{MMHg}$ analyses were frozen $\left(-18{ }^{\circ} \mathrm{C}\right)$ in metal-free $20-\mathrm{mL}$ glass tubes prior to freeze drying. Larvae wet and dry weights were weighed individually (L. Muuratjärvi rivers) and in pooled groups of five individuals (all the rivers) on homemade foil cups with a micro-analytical balance (GWB Mettler Toledo XP56, $d=0.001 \mathrm{mg}$ ) prior to and after drying to constant weight at $60{ }^{\circ} \mathrm{C}$. Larvae for wet weight measurement were gently blotted dry on hand towels for a few seconds. Comparison of individual weights to pooled weights with the L. Muuratjärvi river larvae revealed that pooled weighing gave reliable larvae mass values.

A dissecting stereo microscope was utilized for larvae and pupa identification, and head capsule microscopic slides were made for further identification with a light microscope. According to the identification key of Jensen (1997) for pupa and full-grown larvae, larvae from all the rivers were identified as Simulium spp.

\subsection{River Water Quality Measurements}

Water quality was measured on site during the larvae samplings for water temperature, $\mathrm{pH}$, oxygen concentration and saturation, and conductivity with a portable data sonde (YSI V2 6600). Water temperature at the time of the samplings varied from 17.5 to $12.6{ }^{\circ} \mathrm{C}$ northwards. In addition, $100 \mathrm{~mL}$ of water from each river was sampled into pyrex class bottles for dissolved organic carbon (DOC, a proxy of DOM) and total dissolved nitrogen (TDN) determination (Shimadzu TOC-VCPH TOC-L, TNM-L). Concentrations of DOC and TDN were determined against oven-dried $\left(2 \mathrm{~h}, 120{ }^{\circ} \mathrm{C}\right)$ carbon (potassium hydrogen phthalate, KHP, as a carbon source) and nitrogen (potassium nitrate, $\mathrm{KNO}_{3}$, as a carbon source) calibration standards. Known reference materials were analyzed in the same sample lot prior and after the samples, as well as ultrapure water samples, for which the instrument background was corrected. All containers were machine and acid washed and soaked in ultrapure deionized water. 


\subsection{Blackfly Larvae Mercury Analysis}

Total Hg in the dried blackfly larvae samples was measured with a direct mercury analyzer with a dual cell detection range (Milestone DMA-80). The method is based on direct sample thermal decomposition in an oxygen atmosphere, transport of mercury vapors to the catalyst tube, where the impurities are filtered and mercury species are reduced to elemental mercury, followed by mercury amalgamation on gold, desorption from the gold trap at $850{ }^{\circ} \mathrm{C}$, and atomic absorption spectrophotometer detection at $253.65 \mathrm{~nm}$ (USEPA 2007). Aliquots of $19 \pm 7-\mathrm{mg}$ dried samples were weighed (Mettler Toledo AE 100 Analytical balance) on soapwashed, rinsed, and annealed $\left(450{ }^{\circ} \mathrm{C}\right)$ sample boats. System blanks, as well as National Research Council of Canada and National Institute of Standards and Technology reference materials certified for $\mathrm{THg}$ in tissues (NRC Tort-2 Lobster hepatopancreas, NIST 1566a Oyster Tissue), were analyzed to ascertain data quality. All samples including reference materials were analyzed in duplicate. System blanks were well below sample concentrations, and reproducibility of duplicate sample determination varied between 0.1 and $8.2 \%$, except for two samples, where it was 19.0 and $24.0 \%$. Reference materials were in the certified range being $0.0611 \mathrm{mg} \mathrm{kg}^{-1} \mathrm{dw}$ for the oyster tissue and $0.2961 \mathrm{mg} \mathrm{kg}^{-1} \mathrm{dw}$ for the lobster hepatopancreas, respectively.

\subsection{Blackfly Larvae Methylmercury Analysis}

For the MMHg analyses, $53 \pm 3 \mathrm{mg}$ dried blackfly larvae samples were weighed (Mettler Toledo AE 100 Analytical balance) into $40-\mathrm{mL}$ glass vials (Thermo Scientific clear VOA glass vial with 0.12 in. septa), immersed into $5 \mathrm{~mL}$ of $20 \% \mathrm{KOH}(w / v)$ in methanol $(\mathrm{MeOH})$, digested at $50-60{ }^{\circ} \mathrm{C}$ for $11 \mathrm{~h}$, and thereafter further diluted to $10 \mathrm{~mL}$ with $20 \% \mathrm{KOH}$ in $\mathrm{MeOH}$. Hundred microliters of the alkaline digests was added to $30 \mathrm{~mL}$ of deionized water and brought to $\mathrm{pH}$ five by adding $225 \mu \mathrm{L}$ of sodium acetate buffer $(2 \mathrm{M})$. Finally, monomethylmercury (MMHg) was ethylated by adding $30 \mu \mathrm{L}$ of sodium tetratethylborate $(1 \%, w / v$, in $0.5 \mathrm{M}$ $\mathrm{KOH}) . \mathrm{MMHg}$ was then measured using an automated methylmercury analyzer (Tekran 2700), employing purging and trapping of ethylated $\mathrm{Hg}$ species onto Tenax, followed by thermodesorption, gas chromatographic separation, and atomic fluorescence detection.
Concentrations were quantified using an external calibration method. Triplicate system blanks and an NRC reference material (Tort-2 Lobster hepatopancreas) were analyzed to ascertain data quality. System blanks were well below sample concentrations, and the NRC reference material yielded $150.0 \mathrm{ng} \mathrm{g}^{-1} \mathrm{dw}$, which is well within its certified range of $152 \pm 13 \mathrm{ng} \mathrm{g}^{-1} \mathrm{dw}$. One sample was analyzed as duplicate yielding $10.0 \%$ residual deviance. Matrix spikes yielded $93 \%$ recovery of the analyte. All reagents used were HPLC grade.

\subsection{Study Site Catchment Land-Use Data}

To define land-use activities separately for inflow river catchments and the whole lake catchments relevant for the lake outflow river blackfly larvae sampling point, land-use percentages were retrieved from the Finnish Environment Institute's database CORINE Land Cover 2012 using VALUE-application. CORINE Land Cover 2012 describes the land-use activities and land cover in Finland, and the database was updated November 2014 according to the prevailing situation. At the time of the study reporting, this database was the newest available for the study. There has not been remarkable changes in the land covers or land-use activities in the study areas between November 2014 and the blackfly larvae sampling time in May to June in 2016 other than those specified in the discussion.

The database's resolution is 1 ha. It groups land-uses into five main classes: urban, agricultural, forested, wetlands, and open water. Class 'urban' includes all anthropogenic areas such as residential, recreational, industrial, services, traffic and transport, landfill, construction sites, and soil excavation; class 'agricultural' farmlands, pasturelands, and other heterogenic agricultural areas; and class 'forested' young and old forests, brushes, and moors. Lake surface areas and mean depths were retrieved from the Finnish Environment Institute's open database.

\subsection{Lake Fish Data}

National monitoring data for comparison of $\mathrm{Hg}$ concentrations between blackfly larvae and pike was acquired from other investigations, which were Mykrä et al. (2015), Korhonen et al. (2016); Talvivaara/Terrafame mine monitoring reports $(2014,2015,2016,2017)$ and the open database (2000-2014) of the Finnish Environment Institute (2018) (Table 2). Pikes from all the study 
lakes were caught during 2000-2016. Data of perch Hg concentrations was only available for four lakes, and it was excluded from the analyses. Because fish $\mathrm{Hg}$ concentrations are known to be positively related to fish age and size, pike $\mathrm{Hg}$ muscle concentrations were standardized individually for each lake by partial regression coefficients for weight of $1.0 \mathrm{~kg}$ and length of $52.5 \mathrm{~cm}$ of northern pike according to Miller et al. (2013) and equation (1):

$$
\begin{aligned}
\mathrm{THg}_{\text {Stand }}= & \mathrm{THg}_{\text {Obs }}+b_{\mathrm{W}} \times\left(W_{\text {Stand }}-W_{\mathrm{Obs}}\right)-b_{\mathrm{L}} \\
& \times\left(L_{\text {Stand }}-L_{\mathrm{Obs}}\right),
\end{aligned}
$$

where $\mathrm{THg}_{\text {Stand }}$ is the standardized size (weight and length adjusted, $\left.\mathrm{mg} \mathrm{kg}^{-1} \mathrm{ww}\right), \mathrm{THg}_{\text {Obs }}$ the observed pike muscle THg in a lake ( $\left.\mathrm{mg} \mathrm{kg}^{-1} \mathrm{ww}\right), \mathrm{b}_{\mathrm{W}}$ and $b_{\mathrm{L}}$ the regression coefficients for pike weight or length and THg in a lake, $W_{\text {Stand }}$ and $L_{\text {Stand }}$ the standardized weights and lengths, and $W_{\mathrm{Obs}}$ and $L_{\mathrm{Obs}}$ the observed weights and lengths. Fish MMHg was assumed $95 \%$ of the THg concentration (Bloom 1992; Lasorsa and Allen-Gil 1995; Westöö 1973).

\subsection{Statistics}

Spearman's nonparametric rank-order correlation was used to examine association of larval THg concentrations with larval MMHg concentrations across all rivers $(n=12)$. It was further used to test associations of larval $\mathrm{MMHg}$ concentrations with the size adjusted lake pike mean $\mathrm{THg}$ concentrations, water quality variables $(\mathrm{pH}$, conductivity, DOC, and TDN concentrations), and catchment size and land-use activities. These correlations were run separately for lake inflow and lake outflow data $(n=6)$ due to autocorrelation between lake inflows and outflows (inflow catchment is included in the outflow catchment). Nonparametric Mann-Whitney $U$ test was used to examine if the studied variables differed between the mining-affected and the nonaffected rivers and the lake inflows and outflows. The data did not adequately meet the assumptions for the use of parametric testing methods such as data normality and homogeneity of variances. Tests were performed with IBM SPSS Statistics version 24, and a significance level of $\alpha=0.05$ was used.

\section{Results}

The $\mathrm{THg}$ concentrations in blackfly larvae varied between 0.03 and 0.31 (mean $0.12 \pm 0.08) \mathrm{mg} \mathrm{kg}^{-1} \mathrm{dw}$ and $\mathrm{MMHg}$ concentrations between 0.02 and 0.25 (mean $0.09 \pm 0.07$ ) $\mathrm{mg} \mathrm{kg}^{-1} \mathrm{dw}$ (Fig. 2). The dry weight based proportion of $\mathrm{MMHg}$ of THg in the larvae was on average $74.3( \pm 0.16)$ $\%$, with a range of $42.6-97.7 \%$. The highest average $\mathrm{THg}$ concentrations in the larvae were measured in the inflows of lakes Jormasjärvi and Kivijärvi (Fig. 2), which both have received mine effluents. Larvae THg and MMHg in the inflow of the mining-affected L. Jormasjärvi were 2.7 and 2.9 times higher than the mean concentrations observed in the other non-affected lake inflows. Overall, the larval dry weight-based $\mathrm{THg}$ and $\mathrm{MMHg}$ concentrations were higher in the lake inflows compared to outflows, except for L. Ukonjärvi (Fig. 2). A statistically significant difference was observed for larvae THg $(U=5, p<0.05)$, but not for MMHg $(U=6, p=0.055)$. The highest larval $\mathrm{MMHg}$ concentrations were measured in the inflows of the mining-affected lakes Jormasjärvi (R. Tuhkajoki) and Kivijärvi (R. Lumijoki) and the non-affected Lievestuoreenjärvi (R. Hohonjoki). When inspecting the inflows and outflows together, no statistically significant differences were found in larval dry weight based THg or $\mathrm{MMHg}$ between the mining-affected and the non-affected rivers (THg: $U=8, p=0.174$; MMHg: $U=6, p=0.089$ ).

All river catchments were mostly forested, based on the newest available 2012 land use data, the proportion ranging from 70.3 to $92.1 \%$, and was highest in the pristine dystrophic L. Ukonjärvi area (Table 1). Wetlands accounted for $0.8-6.6 \%$ of the catchments, depending on the river, being also highest in L. Ukonjärvi area. The proportions of open water and urban land-use varied between $0.7-19.9 \%$ and $0.1-17.9 \%$, respectively. Agriculture accounted for up to $11.3 \%$ and it varied from 0 to $1.5 \%$ in the two mining-affected lakes Kivijärvi and Jormasjärvi and the non-affected L. Ukonjärvi. The proportion of urban catchment was significantly higher in the mining-affected than in the nonaffected rivers $(U=4, p<0.05)$. The proportion of open water in the lake outflow catchments was obviously significantly higher than in the inflow catchments $(U=3, p<0.05)$. There were no differences in the proportions of other land-use activities in the catchments between the mining-affected and non-affected rivers, nor between the lake inflows and outflows.

All the river waters were well oxygenated, with oxygen concentrations varying between 8.2 and 
Table 2 Measured and size adjusted pike mean (min-max) THg in the study lakes. Lakes Kivijärvi and Jormasjärvi have received mining effluents since 2008

\begin{tabular}{|c|c|c|c|c|c|}
\hline Lake & $n$ & Sampling year & $\begin{array}{l}\text { Observed } \mathrm{THg} \\
\mathrm{mg} \mathrm{kg}^{-1} \text { ww }\end{array}$ & $\begin{array}{l}\text { Size adjusted THg } \\
\mathrm{mg} \mathrm{kg}^{-1} \text { ww }\end{array}$ & References \\
\hline Muuratjärvi & 5 & 2006-2007 & $0.66(0.28-1.10)$ & $0.62(0.25-1.00)$ & Mykrä et al. (2015) \\
\hline Petäjävesi & 7 & 2006-2007 & $0.69(0.42-0.93)$ & $0.61(0.17-0.92)$ & Mykrä et al. (2015) \\
\hline Lievestuoreenjärvi & 10 & 2000 & $0.53(0.31-0.67)$ & $0.56(0.30-0.74)$ & $\begin{array}{l}\text { Finnish Environment Institute's } \\
\text { database (2018) }\end{array}$ \\
\hline Ukonjärvi & 24 & $2013,2014,2015$ & $1.06(0.61-2.30)$ & $1.08(0.63-2.43)$ & $\begin{array}{l}\text { Talvivaara Sotkamo Ltd. bankrupt's } \\
\text { estate (2015) } \\
\text { Korhonen et al. (2016) }\end{array}$ \\
\hline Kivijärvi & 29 & $\begin{array}{l}2012,2013,2014 \\
\quad 2015\end{array}$ & $0.75(0.31-1.30)$ & $0.77(0.27-1.43)$ & Korhonen et al. (2016) \\
\hline Jormasjärvi & 24 & $\begin{array}{l}2013,2014,2015 \\
\quad 2016\end{array}$ & $0.69(0.27-2.10)$ & $0.73(0.13-1.79)$ & $\begin{array}{l}\text { Talvivaara Ltd. (2014) } \\
\text { Talvivaara Sotkamo Ltd. bankrupt's } \\
\quad \text { estate (2015) } \\
\text { Terrafame Ltd. }(2016,2017) \\
\text { Korhonen et al. }(2016)\end{array}$ \\
\hline
\end{tabular}

$10.5 \mathrm{mg} \mathrm{L}^{-1}$. DOC concentrations varied from 6.9 to $18.1 \mathrm{mg} \mathrm{L}^{-1}$. Water $\mathrm{pH}$ varied between 5.6 and 7.0 with rivers draining their waters into and out of L. Ukonjärvi being the most acidic, and rivers situated in the lakes Muuratjärvi and Kivijärvi catchments being the least acidic. As expected, conductivity was the highest in rivers having received the biomining effluents with levels up to $585 \mu \mathrm{S} \mathrm{cm}^{-1}$. Conductivity differed significantly between the mining-affected and the nonaffected rivers $(U=0, p<0.05)$. The DOC and mostly TDN levels were smaller in the lake outflows compared to inflows with their proportions ranging from 55.6 to $78.8 \%$ for DOC and from 66.1 to $109.7 \%$ for TDN (DOC: $U=4, p<0.05$; TDN: $U=3.5, p<0.05$; Table 3 ). Other water quality variables did not differ between the in- and outflows.

The pike size adjusted mean $\mathrm{THg}$ ranged from 0.56 to $1.08 \mathrm{mg} \mathrm{kg}^{-1}$ ww for the studied lakes (Table 2). The lowest $\mathrm{THg}$ concentrations were observed in $\mathrm{L}$. Lievestuoreenjärvi pike, and the highest in the fish from L. Ukonjärvi, both of which were not affected by the multimetal biomining activities. In overall, there were no differences in the pike size standardized THg concentrations between the mining-affected and the non-affected lakes $(U=8, p=0.170)$. Blackfly larvae MMHg concentrations in the lake outflows correlated strongly with the size-standardized pike THg $\left(r^{2}=0.943, p=0.005\right)$, but in the lake inflows, no such association was observed $\left(r^{2}=-\right.$ $0.371, p=0.468$ ) (Fig. 3, Table 4).
Larval MMHg concentration correlated strongly with that of THg (IF: $r_{\mathrm{s}}=0.771, p=0.072$; OF: $r_{\mathrm{s}}=0.886, p=$ 0.019 ; Fig. 3, Table 4). Of the inflow water quality variables inspected, only conductivity correlated statistically significantly with the MMHg levels in the larvae $\left(r_{\mathrm{s}}=\right.$ $0.886, p=0.019$; Fig. 3, Table 4). Lake catchment area and the proportions of lake catchment agricultural area and open water area relevant for the lake outflow river sampling point were all negatively correlated with the $\mathrm{MMHg}$ levels in the larvae $\left(r_{\mathrm{s}}=-0.943, p=0.005 ; r_{\mathrm{s}}=-0.928\right.$, $p=0.008 ; r_{\mathrm{s}}=-0.771, p=0.072$, respectively; Table 4). In contrast, outflow larval MMHg body burdens tended to be higher as the catchments' urban, mining, forested, and wetland proportions increased $\left(r_{\mathrm{s}}=0.314, p=0.544 ; r_{\mathrm{s}}=\right.$ $0.273, p=0.600 ; r_{\mathrm{s}}=0.543, p=0.266 ; r_{\mathrm{s}}=0.657, p=$ 0.156 , respectively; Fig. 3, Table 4). Same trends were observed with the pike size adjusted THg concentration and the lake outflow land-use activities. In the lake inflows with much smaller catchment areas, these associations were much weaker or negligible (Fig. 3, Table 4). Mean individual larval wet weights were $2.63 \pm 0.86 \mathrm{mg}( \pm \mathrm{SD})$ and ranged in lake inflows $1.94 \pm 0.20 \mathrm{mg} w \mathrm{w}$ to $5.01 \pm$ $1.77 \mathrm{mg} w \mathrm{w}$ in lake outflows. They consistently reflected the site-specific abundance of larval stages at the time of the sampling, and so being the lowest in L. Jormasjärvi outflow R. Jormasjoki and highest in L. Muuratjärvi inflow R. Myllyjoki. The mean larval dry weights did not differ between the mining-affected and the non-affected rivers $(U=14, p=0.734)$ nor between the lake inflows and 


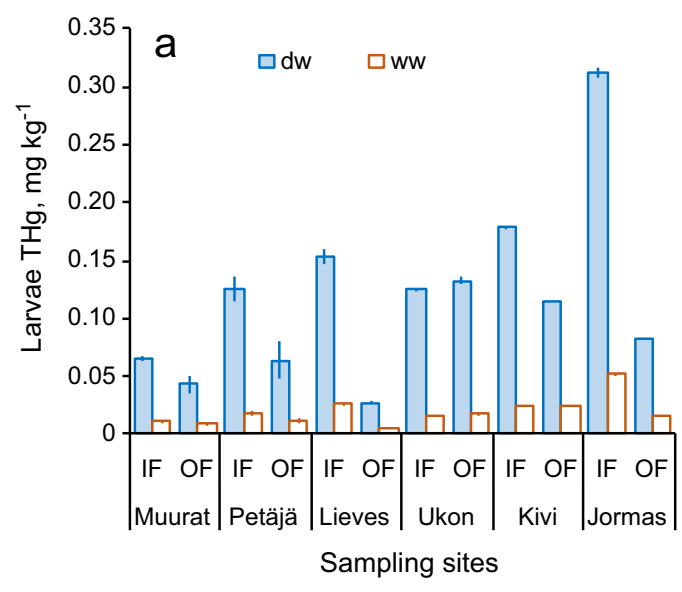

Fig. 2 Mean $( \pm S D)$ wet and dry weight-based concentrations of $\mathrm{THg}$ (a) as well as THg and MMHg dry weight concentrations (b) for blackfly larvae in the lake inflows (IF) and outflows (OF).

outflows $(U=13, p=0.423)$. There appeared a general trend of increasing MMHg proportion with higher larval developmental stage (larvae dry weight) (Fig. 3). Mean pupal wet weights were $2.87 \pm 0.90 \mathrm{mg}$ (rivers Myllykoski, Muuratjoki and Piesalanjoki). Dry to wet weight ratios were $0.17 \pm 0.03$ (SD) for larvae and 0.17 \pm 0.05 for pupal stages.

\section{Discussion}

The mining-affected rivers were characterized by higher conductivity and on average higher urban and obviously mining land-use activity proportion in their catchments.

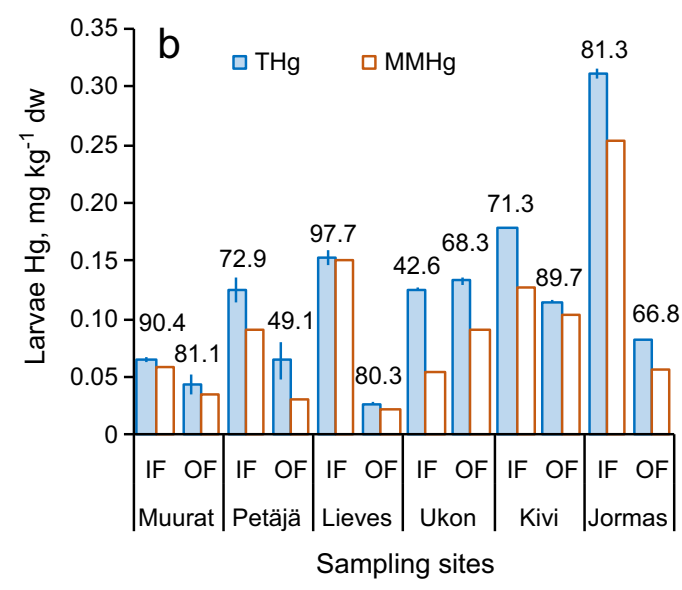

Number above the bars represents the percentage of $\mathrm{THg}$ that is $\mathrm{MMHg}$

Higher conductivity signifies increased salinity of the waters due to dissolved anions such as $\mathrm{SO}_{4}$ and cations such as calcium typical in many mining effluents, also the studied area (Arola et al. 2019; Karjalainen et al. 2020; Salmelin et al. 2017; Sivula et al. 2018). The gathered blackfly larvae species Simulium spp. showed high MMHg to THg levels, and the THg concentrations were significantly higher in the lake inflows than in the outflows with one exception, but when inspecting the whole data, not affected by the biomining activities. Yet, the mean $\mathrm{THg}$ concentrations were almost three times higher in the inflows of lakes Jormasjärvi and Kivijärvi having received the mine effluents since 2008 compared to other lakes' inflows. This indicates $\mathrm{SO}_{4}$

Table 3 Water quality characteristics of the lake inflow (IF) and outflow (OF) rivers. Lakes Kivijärvi and Jormasjärvi have received mining effluents through their inflow rivers Lumijoki and Tuhkajoki since 2008

\begin{tabular}{|c|c|c|c|c|c|c|c|}
\hline Lake & Study rivers & $\mathrm{pH}$ & Conductivity $\mu \mathrm{S} \mathrm{cm}^{-1}$ & DOC mg L ${ }^{-1}$ & OF $\%$ of IF DOC & TDN mg L ${ }^{-1}$ & $\begin{array}{l}\text { OF } \% \text { of IF } \\
\text { TDN }\end{array}$ \\
\hline Muuratjärvi & $\begin{array}{l}\text { IF: Myllyjoki } \\
\text { OF: Muuratjoki }\end{array}$ & $\begin{array}{l}6.80 \\
7.00\end{array}$ & $\begin{array}{l}35 \\
40\end{array}$ & $\begin{array}{l}11.5 \\
6.9\end{array}$ & 60.50 & $\begin{array}{l}0.47 \\
0.43\end{array}$ & 92.26 \\
\hline Petäjävesi & $\begin{array}{l}\text { IF: Pengerkoski } \\
\text { OF: Piesalanjoki }\end{array}$ & $\begin{array}{l}6.10 \\
6.90\end{array}$ & $\begin{array}{l}22 \\
25\end{array}$ & $\begin{array}{l}18.1 \\
14.1\end{array}$ & 77.99 & $\begin{array}{l}0.42 \\
0.46\end{array}$ & 109.73 \\
\hline Lievestuoreenjärvi & $\begin{array}{l}\text { IF: Hohonjoki } \\
\text { OF: Tarvaalankoski }\end{array}$ & $\begin{array}{l}6.40 \\
6.60\end{array}$ & $\begin{array}{l}51 \\
37\end{array}$ & $\begin{array}{l}13.2 \\
7.3\end{array}$ & 55.61 & $\begin{array}{l}0.54 \\
0.36\end{array}$ & 66.11 \\
\hline Ukonjärvi & $\begin{array}{l}\text { IF: Tuohenjoki } \\
\text { OF: Ukonjoki }\end{array}$ & $\begin{array}{l}5.80 \\
5.60\end{array}$ & $\begin{array}{l}19 \\
16\end{array}$ & $\begin{array}{l}14.4 \\
11.4\end{array}$ & 78.75 & $\begin{array}{l}0.43 \\
0.29\end{array}$ & 68.83 \\
\hline Kivijärvi & $\begin{array}{l}\text { IF: Lumijoki } \\
\text { OF: Kivijoki }\end{array}$ & $\begin{array}{l}6.70 \\
7.00\end{array}$ & $\begin{array}{l}145 \\
585\end{array}$ & $\begin{array}{l}17.0 \\
11.9\end{array}$ & 70.0 & $\begin{array}{l}0.51 \\
0.37\end{array}$ & 72.80 \\
\hline Jormasjärvi & $\begin{array}{l}\text { IF: Tuhkajoki } \\
\text { OF: Jormasjoki }\end{array}$ & $\begin{array}{l}6.60 \\
6.10\end{array}$ & $\begin{array}{l}553 \\
241\end{array}$ & $\begin{array}{l}12.6 \\
9.4\end{array}$ & 74.2 & $\begin{array}{l}0.49 \\
0.39\end{array}$ & 78.85 \\
\hline
\end{tabular}



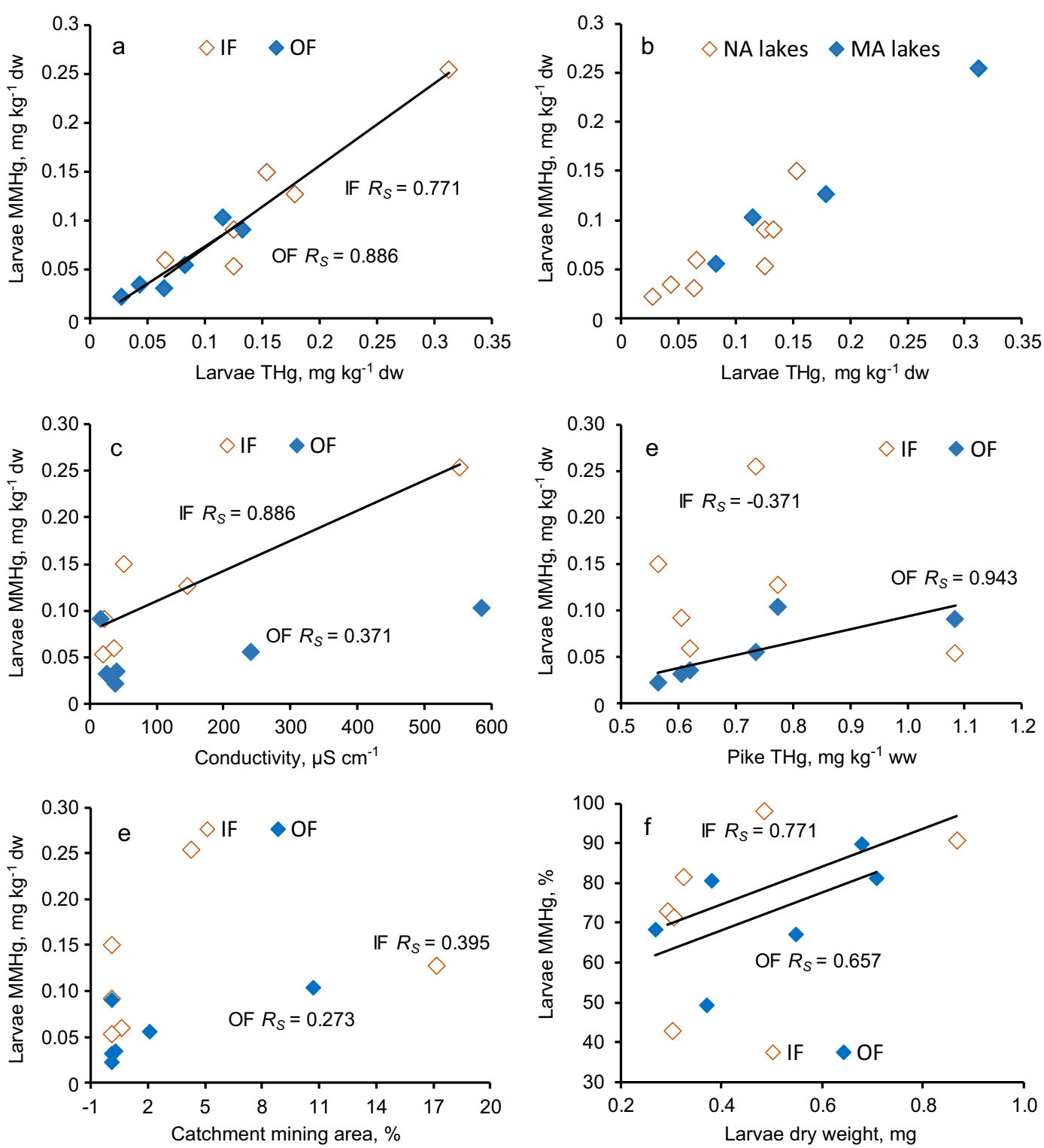

Fig. 3 The relationship between blackfly larvae MMHg and a, b larvae $\mathrm{THg}$, $\mathbf{c}$ water conductivity, $\mathbf{d}$ size adjusted pike $\mathrm{THg}$, and e catchment mining areas $\%$ and $\mathbf{f}$ larvae dry weight with their

contamination from the mine may have enhanced $\mathrm{Hg}$ biomethylation in the studied lake catchment river sediments and wetlands by producing favorable conditions for the SRB known to be capable of performing $\mathrm{Hg}$ methylation (Compeau and Bartha 1985; Gilmour et al. 1992; King et al. 1999).

Harding et al. (2006) have found that the proportion of MMHg in Simulium spp. in the District of Muskoka and Haliburton County, Ontario, Canada, was 58.2$93.0 \%$ in the absence of $\mathrm{Hg}$ point source pollution.

Spearman's rank correlation coefficients (Rs). Abbreviations: lake inflow (IF), lake outflow (OF), non-mining-affected river (NA), and mining-affected river (MA)

The larval THg body burdens at $0.03-0.31 \mathrm{mg} \mathrm{kg}^{-1}$ $\mathrm{dw}$ in our study from central Finland in northern Europe were roughly half of those measured by Harding et al. (2006), between 0.06 and $0.64 \mathrm{mg} \mathrm{kg}^{-1} \mathrm{dw}$ (no gut content purging). They were, however, much lower than those determined by Daniel and McCreadie (2014) at Alabama coastal plain USA after gut content purging, between 0.28 and $1.77 \mathrm{mg} \mathrm{kg}^{-1} \mathrm{dw}$. Yet, the larvae MMHg proportions of 42.6 to $97.7 \%$ in this study are concordant with the findings of Harding et al. (2006), 
Table 4 Spearman's rank correlation coefficients $\left(R_{S}\right)$ between blackfly larvae MMHg concentrations and their THg concentrations, lake pike size adjusted $\mathrm{THg}$ concentrations, water quality variables, catchment areas and land-use in the lake inflows and outflows

\begin{tabular}{|c|c|c|c|c|}
\hline & \multicolumn{2}{|l|}{ IF } & \multicolumn{2}{|l|}{ OF } \\
\hline & $R_{\mathrm{s}}$ & $p$ & $R_{\mathrm{s}}$ & $p$ \\
\hline Blackfly larvae $\mathrm{THg}, \mathrm{mg} \mathrm{kg}^{-1} \mathrm{dw}$ & 0.771 & 0.072 & $0.886^{\mathrm{a}}$ & $0.019^{\mathrm{a}}$ \\
\hline Pike size adjusted $\mathrm{THg}, \mathrm{mg} \mathrm{kg}^{-1} \mathrm{ww}$ & -0.371 & 0.468 & $0.943^{\mathrm{a}}$ & $0.005^{\mathrm{a}}$ \\
\hline $\mathrm{Ph}$ & 0.257 & 0.623 & -0.086 & 0.872 \\
\hline Conductivity, $\mu \mathrm{S} \mathrm{cm}{ }^{-1}$ & $0.886^{\mathrm{a}}$ & $0.019^{\mathrm{a}}$ & 0.371 & 0.468 \\
\hline $\mathrm{DOC}, \mathrm{mg} \mathrm{L}^{-1}$ & -0.143 & 0.787 & 0.314 & 0.544 \\
\hline $\mathrm{TDN}, \mathrm{mg} \mathrm{L}^{-1}$ & 0.657 & 0.156 & -0.314 & 0.544 \\
\hline Catchment area, $\mathrm{km}^{2}$ & -0.029 & 0.957 & $-0.943^{\mathrm{a}}$ & $0.005^{\mathrm{a}}$ \\
\hline Catchment urban area, $\%$ & 0.371 & 0.468 & 0.314 & 0.544 \\
\hline Catchment mining area, $\%$ & 0.395 & 0.439 & 0.273 & 0.600 \\
\hline Catchment agricultural area, $\%$ & 0.265 & 0.612 & $-0.928^{\mathrm{a}}$ & $0.008^{\mathrm{a}}$ \\
\hline Catchment forested area, $\%$ & -0.314 & 0.544 & 0.543 & 0.266 \\
\hline Catchment wetlands area, $\%$ & -0.486 & 0.329 & 0.657 & 0.156 \\
\hline Catchment open water area, $\%$ & 0.200 & 0.704 & -0.771 & 0.072 \\
\hline
\end{tabular}

${ }^{a}$ Significant correlations are shown in italics

approaching those found in predatory insect species (Haines et al. 2003; Mason et al. 2000; Tremblay et al. 1996), and commonly found in the edible parts of predatory fish (e.g., Hammerschmidt and Fitzgerald 2006; Ward et al. 2010; Westöö 1973). Herbivorous insect species have between $15 \%$ and $50 \%$ of their $\mathrm{THg}$ in the form of MMHg (Mason et al. 2000), while in predatory species, such as dragonflies, $\mathrm{MMHg}$ ranges from $68 \%$ to $95 \%$ of the $\mathrm{THg}$ (Haines et al. 2003; Mason et al. 2000; Tremblay et al. 1996). The caddisfly, Hydropsyche morosa (Trichoptera, Hydropsychidae), has been shown to have lower $\mathrm{THg}$ concentration when consuming algae and detritus, and higher when consuming detritus alone (Snyder and Hendricks 1995). Our data indicates that blackfly at their last larval developmental stages prior to their puparium can have $\mathrm{MMHg}$ to $\mathrm{THg}$ proportions similar to those found in predatory insects.

High MMHg to THg proportions in the blackfly larvae was most likely due to their unique feeding habits in that they feed mostly on detritus, fine particulate and DOM in running waters. Dissolved organic matter is suggested to be a direct and significant food source to Simuliidae larvae (Ciborowski et al. 1997; Hershey et al. 1996; Morin et al. 1988; Ross and Craig 1980; Wotton 1978). In aquatic environments, DOM is also known to effectively bind inorganic $\mathrm{Hg}$ and $\mathrm{MMHg}$
(Driscoll et al. 2013; Ravichandran 2004). Blackfly larvae can thus directly take up DOM-bound MMHg from the water column. This may facilitate bioaccumulation of $\mathrm{MMHg}$ in food webs, because larvae themselves, and flying adults, are prey for various insects (Malmqvist and Sackmann 1996), fish, and bird predators. Thus, blackfly larvae can be important suppliers of MMHg to aquatic and terrestrial food webs. The interactions between DOM and mercury, however, are complex, and DOM may either inhibit or promote the formation of MMHg (Bishop et al. 2020; Bravo et al. 2017; Driscoll et al. 2013; Ravichandran 2004).

In the six lake outflows, we observed a trend of increasing concentrations of $\mathrm{THg}$ and $\mathrm{MMHg}$ in blackfly larvae with decreasing $\mathrm{pH}$ and with increasing DOC. Harding et al. (2006) have found a strong negative correlation with larval $\mathrm{Hg}$ and water $\mathrm{pH}$ and a positive correlation with DOC and $\mathrm{Hg}$ in larvae in pristine Canadian streams. In our study rivers, catchment forest and wetland proportions were related to the $\mathrm{Hg}$ concentration in blackfly larvae. Wetlands can increase the runoff of humic substances and DOM, increasing therefore the transport of DOM-bound Hg into the rivers and lakes, and can act as sinks and facilitate $\mathrm{Hg}$ biomethylation (Lane et al. 2018). Leaching of MMHg from soils to surface waters may be increased by soil disturbance, which promotes $\mathrm{Hg}$ biomethylation 
(Braaten and de Wit 2016; Hsu-Kim et al. 2018; Porvari et al. 2003; Wu et al. 2018). In the present study, the proportion of open water was negatively related to larval MMHg in the lake outflows. Upstream lakes may act as sinks for DOM and DOM-bound $\mathrm{Hg}$, resulting in decreasing $\mathrm{Hg}$ concentrations in the downstream surface waters (Lindqvist et al. 1991), and yielding to the observation of higher larvae $\mathrm{THg}$ and $\mathrm{MMHg}$ concentrations in the lake inflows compared to outflows.

In support of our hypothesis, lake outflow larvae MMHg concentrations correlated positively with the lake size adjusted pike THg concentrations because outflows are more representative of lake physicochemical characteristics and processes than inflows. Larvae THg was the highest in R. Ukonjoki among the investigated lake outflows. Also, the pike size adjusted mean $\mathrm{THg}$ was the highest in pristine $\mathrm{L}$. Ukonjärvi (1.08 $\left.\mathrm{mg} \mathrm{kg}^{-1} \mathrm{ww}\right)$ and exceeded the maximum pike $\mathrm{THg}$ level of $1.0 \mathrm{mg} \mathrm{kg}^{-1}$ ww set for human consumption in the European Commission Regulation 1881/2006 (EU 2006). Pristine dystrophic L. Ukonjärvi, situated near the mining-affected lakes, does not receive the biomining effluents, but is subject to intensive forestry and peat mining practices in its catchment. Recent deforestation, clearcutting, and ditching were observed in L. Ukonjärvi catchment both near rivers Tuohenjoki (IF) and Ukonjoki (OF) and around the lake itself during the sampling. L. Ukonjärvi also had the highest proportion of wetlands in its catchment. This kind of forestry operations can create $\mathrm{Hg}$ methylation hotspots in disturbed and water-logged soils known to favor methylating micro-organisms, which enhance MMHg formation (Eklöf et al. 2018). Natural and anthropogenic land-use activities induced leaching of $\mathrm{Hg}$ from soils to surface waters, both of which can be compounded by climate change (Bishop et al. 2020; UNEP 2013), were the probable causes for the highest THg in R. Ukonjoki among the studied lake outflows. The mining-affected river Kivijoki also had experienced recent deforestation in its catchment. However, none of the investigated $\mathrm{Hg}$ biota concentrations, i.e., larvae $\mathrm{THg}$, larvae $\mathrm{MMHg}$, and the size-adjusted pike $\mathrm{THg}$ in the mining-affected catchments, was affected by mining activities alone. We conclude that all of the above considered natural and human-driven factor combined to influence the environmental fate of $\mathrm{Hg}$ and its biomagnification potential.
Blackfly larvae filter-feed on detritus, fine particulate, and dissolved organic material in running waters. Due to their feeding habits, the larvae contained higher proportions of $\mathrm{MMHg}$ to $\mathrm{THg}$ than would be expected from such a low trophic level organism. Because larvae themselves are a prey for various higher trophic level insects, fish, and birds, they can enhance MMHg biomagnification in food webs. In our data, blackfly larvae MMHg concentrations in the lake outflows correlated with the size-adjusted lake pike $\mathrm{THg}$ concentrations in boreal catchments. Because blackfly larvae are also easy to gather and have a worldwide distribution in lotic waters, they could be useful indicators for $\mathrm{Hg}$ biomagnification in freshwater systems.

Our research design, however, included only six lakes and their inflows and outflows. Secondly, the larvae in our study represented several larval stages up to the largest stage prior their pupation, which brings an additional and inevitable variation into $\mathrm{Hg}$ tissue concentrations in the larvae. By transformations to next stages, the larvae grow and get bigger in size. Assuming $\mathrm{Hg}$ concentrations in their food items remains constant, one would expect observing higher $\mathrm{Hg}$ concentrations in older larvae. Although there was no significant difference in the larval dry weights between the mining-affected and the non-affected rivers nor between the lake inflows and outflows, we observed, however, a general trend of increasing blackfly larvae MMHg proportion with higher larval developmental stage (measured as larvae dry weight). We used the most recent catchment land-use activity and pike $\mathrm{Hg}$ concentration data available for the study, but as they represented various years, it raises an additional uncertainty into the analysis, which cannot be ruled out. While all these data and method-driven factors leave uncertainties into our analysis, our results nevertheless pointed out that blackfly larvae can be important suppliers of MMHg to aquatic and terrestrial food webs. The complexity of $\mathrm{Hg}$ biochemistry in various boreal catchments as well as the $\mathrm{Hg}$ biomagnification potential still remains a continuing research need.

Acknowledgments We thank Dirk Wallschläger and Doug Evans for enabling this study by providing research infrastructure. We thank Ahti Karusalmi, Mervi Koistinen, and Leena Siitonen for valuable technical assistance, and Heikki Hämäläinen, Dirk Wallschläger, Jussi Kukkonen, and Wei Wang for sharing their expertise. 
Funding Information Open access funding provided by University of Jyväskylä (JYU). The study was financed by the Academy of Finland (contract no 281800) and the University of Jyväskylä mobility grant.

\section{Compliance with Ethical Standards}

Conflict of Interest The authors declare that they have no conflict of interest.

Open Access This article is licensed under a Creative Commons Attribution 4.0 International License, which permits use, sharing, adaptation, distribution and reproduction in any medium or format, as long as you give appropriate credit to the original author(s) and the source, provide a link to the Creative Commons licence, and indicate if changes were made. The images or other third party material in this article are included in the article's Creative Commons licence, unless indicated otherwise in a credit line to the material. If material is not included in the article's Creative Commons licence and your intended use is not permitted by statutory regulation or exceeds the permitted use, you will need to obtain permission directly from the copyright holder. To view a copy of this licence, visit http://creativecommons.org/licenses/by/4.0/.

\section{References}

Adler, P. H., \& Crosskey, R. W. (2016). World blackflies (Diptera: Simuliidae): a comprehensive revision of the taxonomic and geographical inventory (2015). Entomology Program, Clemson University, Clemson, South Carolina, 29634-0310, USA and Department of Entomology, The Natural History Museum, Cromwell Road, London SW7 5BD, UK. https://docplayer.net/14618042-Worldblackflies-diptera-simuliidae-a-comprehensive-revision-ofthe-taxonomic-and-geographical-inventory-2015.html.

Arola, H. E., Karjalainen, A. K., Syrjänen, J. T., Hannula, M., Väisänen, A., \& Karjalainen, J. (2019). Assessment of fish embryo survival and growth by in situ incubation in acidic boreal streams undergoing biomining effluents. Archives of Environmental Contamination and Toxicology, 76(1), 5165. https://doi.org/10.1007/s00244-018-0558-2.

Bishop, K., Shanley, J. B., Riscassi, A., de Wit, H. A., Eklöf, K., Meng, B., Mitchell, C., Osterwalder, S., Schuster, P. F., Webster, J., \& Zhu, W. (2020). Recent advances in understanding and measurement of mercury in the environment: terrestrial Hg cycling. Science of the Total Environment, 721, 15, 137647. https://doi.org/10.1016/j.scitotenv.2020.137647.

Bloom, N. S. (1992). On the chemical form of mercury in edible fish and marine invertebrate tissue. Canadian Journal of Fisheries and Aquatic Sciences, 49, 1010-1017. https://doi. org/10.1139/192-113.

Braaten, H. F. V., \& de Wit, H. A. (2016). Effects of disturbance and vegetation type on total and methylmercury in boreal peatland and forest soils. Environmental Pollution, 218, 140149. https://doi.org/10.1016/j.envpol.2016.08.029.
Braaten, H.F.V., Åkerblom, S., de Wit, H.A., Skotte, G., Rask, M. Vuorenmaa, J., Kahilainen, K.K., Malinen, T., Rognerud, S., Lydersen, E., Amundsen, P-A, Kashulin, N., Kashulina, T., Terentyev, P., Christensen, G., Jackson-Blake, L., Lund, E. \& Rosseland, B.O. (2017). Spatial and temporal trends of $\mathrm{Hg}$ in freshwater fish in Fennoscandia (1965-2017). ICP Waters ICP Waters report 132 / 2017. https://doi.org/10.13140 /RG.2.2.16756.04485.

Bravo, A. G., Bouchet, S., Tolu, J., Björn, E., Mateos-Rivera, A., \& Bertilsson, S. (2017). Molecular composition of organic matter controls methylmercury formation in boreal lakes. Nature Communications, 8, 1-9. https://doi.org/10.1038 /ncomms 14255.

Ciborowski, J. J. H., Craig, D. A., \& Fry, K. M. (1997). Dissolved organic matter as food for black fly larvae (Diptera: Simuliidae). Journal of the North American Benthological Society, 16(4), 771-780. https://doi.org/10.2307/1468170.

Compeau, G. C., \& Bartha, R. (1985). Sulfate-reducing bacteria: principal methylators of mercury in anoxic estuarine sediment. Applied and Environmental Microbiology, 50(2), 498-502 https:/www.ncbi.nlm.nih.gov/pmc/articles/PMC238649/.

Daniel, C. E., \& McCreadie, J. W. (2014). Mercury accumulation in the water column, stream sediments and larval black fly (Diptera: Simuliidae) tissue in coastal streams of Alabama, USA. Water, Air, and Soil Pollution, 225, 1907. https://doi. org/10.1007/s11270-014-1907-z.

Driscoll, C. T., Mason, R. P., Chan, H. M., Jacob, D. J., \& Pirrone, N. (2013). Mercury as a global pollutant: Sources, pathways, and effects. Environmental Science and Technology, 47(10), 4967-4983. https://doi.org/10.1021/es305071v.

Eklöf, K., Bishop, K., Bertilsson, S., Bjorn, E., Buck, M., Skyllberg, U., Osman, O., Kronberg, R., \& Bravo, A. (2018). Formation of mercury methylation hotspots as a consequence of forestry operations. Science of the Total Environment, 613-614, 1069-1078. https://doi.org/10.1016 j.scitotenv.2017.09.151.

EU. (2006). Directives of 20 December 2006/1881/EC as regards setting maximum levels for certain contaminants in foodstuffs. Official Journal of the European Union, 2006(December), 1-24. https://eur-lex.europa.eu/legalcontent/EN/TXT/?uri=celex:32013L0039 Accessed 4/2018.

EU. (2013). Directives of 12 August 2013/39/EC amending Directives 2000/60/EC and 2008/105/EC as regards priority substances in the field of water policy. Official Journal of the European Union, 2013(July), 1-17. http://eur-lex.europa. eu/legal-content/EN/TXT/?uri=celex:32013L0039 . Accessed 4/2018.

Finnish Environment Institute. (2018). National open research and reporting data service of Finnish Environment Institute at Avoindata.fi. Finnish Environment Institute, https://www. syke.fi/en-US/Open_information. Accessed 4/2018.

Gilmour, C. G., Henry, E. A., \& Mitchell, R. (1992). Sulfate stimulation of mercury methylation in freshwater sediments. Environmental Science and Technology, 26(11), 2281-2287. https://doi.org/10.1021/es00035a029.

Haines, T. A., May, T. W., Finlayson, R. T., \& Mierzykowski, S. E. (2003). Factors affecting food chain transfer of mercury in the vicinity of the Nyanza sit, Sudbury river, Massachusetts. Environmental Monitoring and Assessment, 86, 211.232.

Haitzer, M., Aiken, G. R., \& Ryan, J. N. (2003). Binding of mercury(II) to aquatic humic substances: Influence of $\mathrm{pH}$ 
and source of humic substances. Environmental Science and Technology, 37(11), 2436-2441. https://doi.org/10.1021 les026291o.

Hammerschmidt, C. R., \& Fitzgerald, W. F. (2006). Bioaccumulation and trophic transfer of methylmercury in Long Island Sound. Archives of Environmental Contamination and Toxicology, 51(3), 416-424. https://doi. org/10.1007/s00244-005-0265-7.

Harding, K. M., Gowland, J. A., \& Dillon, P. J. (2006). Mercury concentration in black flies Simulium spp. (Diptera, Simuliidae) from soft-water streams in Ontario, Canada. Environmental Pollution, 143(3), 529-535. https://doi. org/10.1016/j.envpol.2005.11.040.

Hershey, A. E., Merritt, R. W., Miller, M. C., \& McCrea, J. S. (1996). Organic matter processing by larval black flies in a temperate woodland stream. Oikos, 75(3), 524-532. https://doi.org/10.2307/3545894.

Hsu-Kim, H., Eckley, C. S., Achá, D., Feng, X., Gilmour, C. C., Jonsson, S., \& Mitchell, C. P. J. (2018). Challenges and opportunities for managing aquatic mercury pollution in altered landscapes. Ambio, 47(2), 141-169. https://doi. org/10.1007/s13280-017-1006-7.

ISO. (1996). European Standard EN ISO 6341:1996, Water quality. Determination of the inhibition of the mobility of Daphnia magna Straus (Cladocera, Crustacea). Acute toxicity test (ISO 6341:1996).

Jensen, F. (1997). Diptera Simuliidae; Blackflies. In A. Nilsson (Ed.), Aquatic insects of North Europe, a taxonomic handbook (Vol. 2, pp. 209-241). Apollo Books, Stenrup.

Karjalainen, A. K., Hallikainen, A., Hirvonen, T., Kiviranta, H., Knip, M., Kronberg-Kippilä, C., et al. (2013). Estimated intake levels for Finnish children of methylmercury from fish. Food and Chemical Toxicology, 54, 70-77. https://doi. org/10.1016/j.fct.2012.02.074

Karjalainen, A. K., Arola, H. E., Syrjänen, J. T., \& Karjalainen, J. (2020). Water quality assessment by in situ whitefish egg incubation. Advances in Limnology. (in press).

King, J. K., Saunders, M. F., Lee, R. F., \& Jahnke, R. A. (1999). Coupling mercury methylation rates to sulfate reduction rates in marine sediments. Environmental Toxicology and Chemistry, 18(7), 1362-1369. https://doi.org/10.1002 /etc.5620180704

Korhonen, P. K., Venäläinen, E.-R., \& Erikson-Kallio, A. M. (2016). Effects of the Talvivaara nickel mine effluents on fish. Natural Resources Institute Finland, Helsinki, 2016. Luonnonvara- ja biotalouden tutkimus, 19 (in Finnish).

Lane, C. R., Leibowitz, S. G., Autrey, B. C., LeDuc, S. D., \& Alexander, L. C. (2018). Hydrological, physical, and chemical functions and connectivity of non-floodplain wetlands to downstream waters: a review. Journal of the American Water Resources Association, 54(2), 346-371. https://doi. org/10.1111/1752-1688.12633.

Lasorsa, B., \& Allen-Gil, S. (1995). The methylmercury to total mercury ratio in selected marine, freshwater, and terrestrial organisms. Water, Air, \& Soil Pollution, 80(1-4), 905-913. https://doi.org/10.1007/BF01189743.

Leino, O., Karjalainen, A. K., \& Tuomisto, J. T. (2013). Effects of docosahexaenoic acid and methylmercury on child's brain development due to consumption of fish by Finnish mother during pregnancy: a probabilistic modeling approach. Food and Chemical Toxicology, 54, 50-58. https://doi.org/10.1016 j.fct.2011.06.052.

Leppänen, J. J., Weckström, J., \& Korhola, A. (2017). Multiple mining impacts induce widespread changes in ecosystem dynamics in a boreal lake. Scientific Reports, 7(1), 1-11. https://doi.org/10.1038/s41598-017-11421-8.

Lindqvist, O., Johansson, K., Aastrup, M., Andersson, A., Bringmark, L., Hovsenius, G., Håkanson, L., Iverfeldt, Å., Meili, M., \& Timm, B. (1991). Mercury in the Swedish environment - Recent research on causes, consequences and corrective methods. Water Air and Soil Pollution, 55(1-2), 1-261. https://doi.org/10.1007/BF00542429.

Malmqvist, B., \& Sackmann, G. (1996). Changing risk of predation for a filter-feeding insect along a current velocity gradient. Oecologia, 108(3), 450-458. https://doi.org/10.1007 /BF00333721.

Mason, R. P., Laporte, J. M., \& Andres, S. (2000). Factors controlling the bioaccumulation of mercury, methylmercury, arsenic, selenium, and cadmium by freshwater invertebrates and fish. Archives of Environmental Contamination and Toxicology, 38(3), 283-297. https://doi.org/10.1007 /s002449910038

Miller, A., Bignert, A., Porvari, P., Danielsson, S., \& Verta, M. (2013). Mercury in perch (Perca fluviatilis) from Sweden and Finland. Water, Air, and Soil Pollution, 224(3). https://doi. org/10.1007/s11270-013-1472-x.

Morin, A., Back, C., Chalifour, A., Boisvert, J., \& Peters, R. H. (1988). Effect of black fly ingestion and assimilation on seston transport in a Quebec lake outlet. Canadian Journal of Fisheries and Aquatic Sciences, 45, 705-714. https://doi. org/10.1139/f88-085.

Munthe, J., Wängberg, I., Rognerud, S., Fjeld, E., Verta, M., Porvari, P., \& Meili, M. (2007). Mercury in Nordic ecosystems. Environmental Research, (IVL Report B1761), IVL Report B1761.

Mykrä, M., Eloranta, A., Koistinen, A., \& Olkio, K. (2015). Pike mercury concentrations in Central Finland. Reports of the Centre for Economic Development, Transport and the Environment of Central Finland 17/2015. (in Finnish).

Porvari, P., Verta, M., Munthe, J., \& Haapanen, M. (2003). Forestry practices increase mercury and methyl mercury output from boreal forest catchments. Environmental Science and Technology, 37(11), 2389-2393. https://doi. org/10.1021/es0340174

Ravichandran, M. (2004). Interactions between mercury and dissolved organic matter - a review. Chemosphere, 55(3), 319 331. https://doi.org/10.1016/j.chemosphere.2003.11.011.

Ross, D.H., \& Craig, D.A. (1980). Mechanisms of fine particle capture by larval black flies (Diptera: Simuliidae). Canadian Journal of Zoology, 58(6), 1186-1192. https://doi. org/10.1139/z80-163.

Salmelin, J., Leppänen, M. T., Karjalainen, A. K., Vuori, K. M., Gerhardt, A., \& Hämäläinen, H. (2017). Assessing ecotoxicity of biomining effluents in stream ecosystems by in situ invertebrate bioassays: a case study in Talvivaara, Finland. Environmental Toxicology and Chemistry, 36(1), 147-155. https://doi.org/10.1002/etc.3511.

Sivula, L., Vehniäinen, E. R., Karjalainen, A. K., \& Kukkonen, J. V. K. (2018). Toxicity of biomining effluents to Daphnia magna: acute toxicity and transcriptomic biomarkers. 
Chemosphere, 210, 304-311. https://doi.org/10.1016/j. chemosphere.2018.07.030.

Snyder, C.D., \& Hendricks, A.C. (1995). Effect of seasonally changing feeding habits on whole-animal mercury concentrations in Hydropsyche morosa (Trichoptera: Hydropsychidae). Hydrobiologia 299(2), 11523. https://doi.org/10.1007/BF00017563.

Talvivaara Ltd. (2014). Talvivaara mine monitoring report $2013-$ Part IVc: fishery monitoring. Pöyry Finland Oy (in Finnish).

Talvivaara Sotkamo Ltd. bankrupt's estate. (2015). Talvivaara mine monitoring report 2014 - Part VII: fishery monitoring. Ramboll Oy, Finland (in Finnish).

Terrafame Ltd. (2016). Terrafame mine monitoring report 2015 part VIII: fishery monitoring. Ramboll Oy, Finland (in Finnish).

Terrafame Ltd. (2017). Terrafame mine monitoring report 2016 part VII: fishery monitoring. Ramboll Oy, Finland (in Finnish).

Tremblay, A., Lucotte, M., Meili, M., Cloutier, L., \& Pichet, P. (1996). Total mercury and methylmercury contents of insects from boreal lakes: ecological, spatial and temporal patterns. Water Quality Research Journal of Canada, 31(4), 851-873. https://doi.org/10.2166/wqrj.1996.047.

UNEP. (2013). Global mercury assessment: sources, emissions, Releases and Environmental Transport. United Nations Programme, UNEP Chemicals Branch, Geneva.

USEPA. (2007). Method 7473 (SW-846): Mercury in Solids and Solutions by Thermal Decomposition, Amalgamation, and Atomic Absorption Spectrophotometry, Revision 0. W a s hington, D C. https:// w w w e pa . gov/sites/production/files/2015-07/documents/epa-7473.pdf.

Verta, M., Kauppila, T., Londersborough, S., Mannio, J., Porvari, P., Rask, M., Vuori, K-M, \& Vuorinen, P.J. (2010). Background levels for metals and monitoring of priority substances in Finnish surface waters - proposal for the implementation of Directive on Environmental Quality Standards. Reports of the Finnish Environment Institute 12/ 2010 .
Wallin, J., Vuori, K. M., Väisänen, A., Salmelin, J., \& Karjalainen, A. K. (2018). Lumbriculus variegatus (Annelida) biological responses and sediment sequential extractions indicate ecotoxicity of lake sediments contaminated by biomining. Science of the Total Environment, 645, 1253-1263. https://doi.org/10.1016/j.scitotenv.2018.07.117.

Ward, D. M., Nislow, K. H., \& Folt, C. L. (2010). Bioaccumulation syndrome: Identifying factors that make some stream food webs prone to elevated mercury bioaccumulation. Annals of the New York Academy of Sciences, 1195, 62-83. https://doi.org/10.1111/j.17496632.2010.05456.x.

Watras, C. J. (2009). Mercury pollution in remote freshwaters. In G. E. Likens (Ed.), Encyclopedia of inland waters, Reference Module in Earth Systems and Environmental Sciences (pp. 100-109). Academic Press. https://doi.org/10.1016/B978012370626-3.00231-3.

Watras, C. J., Back, R. C., Halvorsen, S., Hudson, R. J. M., Morrison, K. A., \& Wente, S. P. (1998). Bioaccumulation of mercury in pelagic freshwater food webs. Science of the Total Environment, 219(2-3), 183-208. https://doi. org/10.1016/S0048-9697(98)00228-9.

Westöö, G. (1973). Methylmercury as percentage of total mercury in flesh and viscera of Salmon and Sea Trout of various ages. Science, 181, 567-568.

Wotton, R. S. (1978). Growth, respiration, and assimilation of blackfly larvae (Diptera: Simuliidae) in a lake-outlet in Finland. Oecologia 33(3), 279-290.

Wu, P., Bishop, K., von Brömssen, C., Eklöf, K., Futter, M., Hultberg, H., et al. (2018). Does forest harvest increase the mercury concentrations in fish? Evidence from Swedish lakes. Science of the Total Environment, 622-623, 13531362. https://doi.org/10.1016/j.scitotenv.2017.12.075.

Publisher's Note Springer Nature remains neutral with regard to jurisdictional claims in published maps and institutional affiliations. 